this 1.5 folds longer interval treatment, respectively. The age of patients in ABT group was $73.5 \pm 10.6$, and significantly higher than those in TCZ $(58.8 \pm 13.9)$ and GOL (58.1 \pm 14.7$)$ groups. At 60 weeks, DAS28 in ABT group was $3.1 \pm 0.5$, and significantly higher than those in TCZ $(2.6 \pm 0.7)$ and GLM $(2.6 \pm 0.7)$ groups. On the other hand, CDAI in GOL was 6.6 \pm 3.4 , and was significantly higher than those in TCZ $(4.4 \pm 2.6)$ or ABT $(4.6 \pm 2.3)$ groups. Accordingly, successive rate at 60th week in ABT group was $52 \%$ and significantly lower than those in TCZ $(69 \%)$ or in GOL $(73 \%)$ groups as shown in figure. Finally, no significant difference in successive rate was observed between s.c. and i.v.

Conclusions: This study clarified that TCZ and GLM had higher successive rate than ABT for maintaining low disease activity for 60 weeks by longer interval treatment. This effectiveness might relate to the high therapeutic efficacy of TCZ and low antigenicity of GOL.

Disclosure of Interest: None declared

DOI: 10.1136/annrheumdis-2018-eular.1464

\section{SAT0167 COMPARISON OF THE EFFICACY AND TOLERABILITY OF TOCILIZUMAB, SARILUMAB, AND SIRUKUMAB IN PATIENTS WITH ACTIVE RHEUMATOID ARTHRITIS: A BAYESIAN NETWORK META-ANALYSIS OF RANDOMIZED CONTROLLED TRIALS}

Y. H. Lee ${ }^{1}$, Y. H. Seo ${ }^{1} .{ }^{1}$ Rheumatology, Korea University Medicial Center, Seoul, Korea, Republic Of

Background: A humanized, anti-human IL-6 receptor monoclonal antibody, tocilizumab, was developed to block IL- 6 signaling and has been used as an effective therapeutic agent for patients that do not respond to methotrexate (MTX) or tumor necrosis factor (TNF) inhibitor. The successful use of tocilizumab in RA stimulated the development of other biologics targeted to the IL-6 pathway, such as anti-IL6R (sarilumab) or anti-IL-6 (sirukumab) antibodies

Objectives: The relative efficacy and tolerability of tocilizumab, sarilumab, and sirukumab were assessed in patients with rheumatoid arthritis (RA) and an inadequate response to MTX or TNF inhibitors.

Methods: We performed a Bayesian network meta-analysis to combine direct and indirect evidence from randomized controlled trials (RCTs) to examine the efficacy and safety of tocilizumab, sarilumab, and sirukumab in RA patients and an inadequate MTX or TNF inhibitor response.

Results: Fourteen RCTs, comprising 9,753 patients, met the inclusion criteria. Tocilizumab $8 \mathrm{mg}$ combined with MTX or as monotherapy was the most effective treatment for active RA with an inadequate MTX or TNF antagonist response, followed by sarilumab and sirukumab, regardless of MTX combination. The ranking probability based on the surface under the cumulative ranking curve (SUCRA) indicated that tocilizumab $8 \mathrm{mg}+\mathrm{MTX}$ had the highest probability of being the best treatment to achieve the ACR50 response rate, followed by tocilizumab $8 \mathrm{mg}$, sarilumab $200 \mathrm{mg}$, sarilumab $200 \mathrm{mg}+\mathrm{MTX}$, sirukumab $100 \mathrm{mg}$, tocilizumab $4 \mathrm{mg}$ +MTX, sirukumab $100 \mathrm{mg}+\mathrm{MTX}$, sirukumab $50 \mathrm{mg}+\mathrm{MTX}$, sarilumab $150 \mathrm{mg}$ +MTX, adalimumab $40 \mathrm{mg}$, and sirukumab $50 \mathrm{mg}$, and placebo+MTX. No significant differences were observed in withdrawals owing to adverse events after treatment with tocilizumab $8 \mathrm{mg}+\mathrm{MTX}$, sirukumab $100 \mathrm{mg}+\mathrm{MTX}$, or sarilumab $200 \mathrm{mg}+$ MTX.

Conclusions: In RA patients with an inadequate MTX or anti-TNF therapy response, tocilizumab $8 \mathrm{mg}$ as monotherapy and combined with MTX showed acceptable tolerability and the highest performance based on the ACR50 response rate, followed by sarilumab and sirukumab.

\section{REFERENCES:}

[1] Smolen JS, Beaulieu A, Rubbert-Roth A, Ramos-Remus C, Rovensky J, Alecock E, Woodworth T, Alten R, Investigators O. Effect of interleukin-6 receptor inhibition with tocilizumab in patients with rheumatoid arthritis (OPTION study): a double-blind, placebo-controlled, randomised trial. The Lancet 2008;371:987-997.

[2] Genovese M, Fleischmann R, Fiore S, Radin A, Fan C, Huizinga T. SAT0117 Sarilumab, a Subcutaneously-Administered, Fully-Human Monoclonal Antibody Inhibitor of The IL-6 Receptor: Relationship Between Eular Responses and Change from Baseline of Selected Clinical Parameters. Annals of the Rheumatic Diseases 2013;72:A620-A620.

[3] Xu Z, Bouman-Thio E, Comisar C, Frederick B, Van Hartingsveldt B, Marini JC, Davis HM, Zhou H. Pharmacokinetics, pharmacodynamics and safety of a human anti-IL-6 monoclonal antibody (sirukumab) in healthy subjects in a first-in-human study. British journal of clinical pharmacology 2011;72:270-281

Disclosure of Interest: None declared DOI: 10.1136/annrheumdis-2018-eular.1644

\section{SAT0168 MRI RESULTS FOLLOWING DISCONTINUATION OF METHOTREXATE IN PATIENTS WITH RHEUMATOID ARTHRITIS TREATED WITH SUBCUTANEOUS TOCILIZUMAB: RESULTS FROM A RANDOMIZED CONTROLLED TRIAL}

C. Peterfy ${ }^{1}$, J. Kremer ${ }^{2}$, W. Rigby ${ }^{3}$, N. Singer ${ }^{4}$, C. Birchwood ${ }^{5}$, D. Gill ${ }^{5}$, W. Reiss ${ }^{5}$, J. Pei ${ }^{5}$, M. Michalska ${ }^{5} .{ }^{1}$ Spire Sciences, Inc., Boca Raton, ${ }^{2}$ Albany Medical College and The Center for Rheumatology, Albany, ${ }^{3}$ Geisel School of Medicine, Dartmouth College, Lebanon, ${ }^{4}$ Case Western Reserve University and the MetroHealth System, Cleveland, ${ }^{5}$ Genentech, Inc., South San Francisico, United States

Background: Although previous studies have established the efficacy of tocilizumab (TCZ) initiated as monotherapy (MONO) for the treatment of rheumatoid arthritis (RA) ${ }^{1,2}$ changes in active intra-articular inflammation after discontinuation of methotrexate (MTX) in patients achieving good clinical control with TCZ + MTX have not been evaluated. Magnetic resonance imaging (MRI) effectively images synovitis and osteitis and can detect changes in bone erosion with greater sensitivity than radiography. ${ }^{3}$

Objectives: This study used MRI to assess differences in joint damage between patients with RA who achieved low disease activity with TCZ + MTX and then continued or discontinued MTX in the COMP-ACT trial (NCT01855789).

Methods: US patients with RA who were inadequate responders to MTX were enrolled; initial combination therapy included MTX ( $>15 \mathrm{mg} /$ week orally) plus TCZ $162 \mathrm{mg}$ subcutaneous (SC) either weekly or every 2 weeks. Patients who achieved DAS28-ESR $\leq 3.2$ at week 24 were randomized 1:1 to receive TCZMONO or continue TCZ + MTX until week 52 (double blind). A subset of these patients was included in this MRI substudy; 1.5 Tesla MRI was used to obtain images of bilateral hands and wrists at Weeks 24 and 40 . Two independent radiologists evaluated images at a central reading facility using RAMRIS (synovitis, osteitis, erosion) and CARLOS (cartilage loss). Outcomes included changes in MRI scores from Week 24 to 40 and the proportion of patients with progression of each score.

Results: Of the 296 patients who achieved DAS28 $\leq 3.2$ at Week 24 and were randomized to TCZ + MTX or TCZ-MONO, 79 were enrolled in the MRI substudy $(n=41$ and 38 , respectively); $74.7 \%$ were women, and the mean (SD) age was 56.3 (12.8) years. Patient demographics in the MRI substudy were similar to overall study demographics. Mean changes from Week 24 to 40 in bone erosion, synovitis, osteitis and cartilage loss scores were not significantly different between the TCZ + MTX and TCZ-MONO groups for both bilateral hands and the dominant hand (table 1). There were no significant differences between the groups in the proportion of patients with no progression in each outcome measure (range, $89.7 \%$ to $97.4 \%$ with TCZ + MTX and $87.9 \%$ to $100.0 \%$ with TCZ-MONO).

Table 1 MRI Changes in Patients Receiving TCZ in Combination With MTX or TCZ as Monotherapy

\begin{tabular}{|c|c|c|c|c|c|c|}
\hline \multirow[b]{2}{*}{$\begin{array}{l}\text { Mean change } \\
\text { from Week } 24 \\
\text { to } 40^{*}\end{array}$} & \multicolumn{3}{|c|}{ Both Hands } & \multicolumn{3}{|c|}{ Dominant Hand } \\
\hline & $\begin{array}{c}\mathrm{TCZ}+\mathrm{MTX} \\
(\mathrm{n}=41)\end{array}$ & $\begin{array}{c}\text { TCZ-MONO } \\
(\mathrm{n}=38)\end{array}$ & $\begin{array}{l}\text { Difference } \\
\text { (95\% CI) (TCZ- } \\
\text { MONO minus } \\
\text { TCZ + MTX) }\end{array}$ & $\begin{array}{c}\mathrm{TCZ}+\mathrm{MTX} \\
(\mathrm{n}=41)\end{array}$ & $\begin{array}{c}\text { TCZ-MONO } \\
(n=38)\end{array}$ & $\begin{array}{c}\text { Difference } \\
\text { (95\% CII) (TCZ- } \\
\text { MONO minus } \\
\text { TCZ + MTX) }\end{array}$ \\
\hline $\begin{array}{l}\text { Bone erosion } \\
\text { score (0-250), } \\
\text { mean (SE) }\end{array}$ & $-0.06(0.18)$ & $0.18(0.19)$ & $\begin{array}{c}0.24 \\
(-0.21 \text { to } 0.68)\end{array}$ & $0.06(0.24)$ & $0.49(0.25)$ & $\begin{array}{c}0.43 \\
(-0.14 \text { to } 1.01)\end{array}$ \\
\hline $\begin{array}{l}\text { Synovitis score } \\
(0-24) \text {, mean } \\
\text { (SE) }\end{array}$ & $-0.24(0.15)$ & $-0.18(0.15)$ & $\begin{array}{c}0.06 \\
(-0.30 \text { to } 0.41)\end{array}$ & $-0.22(0.12)$ & $-0.11(0.12)$ & $\begin{array}{c}0.11 \\
(-0.18 \text { to } 0.40)\end{array}$ \\
\hline $\begin{array}{l}\text { Osteitis score } \\
\text { (0-75), mean } \\
\text { (SE) }\end{array}$ & $-0.16(0.34)$ & $0.37(0.36)$ & $\begin{array}{c}0.53 \\
(-0.30 \text { to } 1.36)\end{array}$ & $-0.39(0.52)$ & $0.69(0.54)$ & $\begin{array}{c}1.07 \\
(-0.18 \text { to } 2.33)\end{array}$ \\
\hline $\begin{array}{l}\text { Cartilage loss } \\
\text { score (0-100). } \\
\text { mean (SE) }\end{array}$ & $0.20(0.14)$ & $-0.03(0.15)$ & $\begin{array}{c}-0.23 \\
(-0.58 \text { to } 0.11)\end{array}$ & $0.11(0.18)$ & $-0.05(0.19)$ & $\begin{array}{c}-0.16 \\
(-0.59 \text { to } 0.27)\end{array}$ \\
\hline
\end{tabular}

MTX, methotrexate; TCZ, tocilizumab; TCZ-MONO, TCZ monotherapy.

"ANCOVA model for estimated means includes Week 24 bone erosion as a covariate, treatment group and the randomization stratification factors: DAS28 remission status at Week $24(<2.6,22.6$ to $\leq 3.2)$, patient anti-TNF exposure
(Yes or No) and baseline weight-by-dosing group ( $<80 \mathrm{~kg} \mathrm{q2w,} 80$ to $<100 \mathrm{~kg}$ q2w, 80 to $<100 \mathrm{~kg}$ qw, $2100 \mathrm{~kg} \mathrm{qw}$ ).

Conclusions: In patients who achieved low disease activity with TCZ + MTX $\mathrm{MRI}$ changes were minimal and showed no difference in the response of active intra-articular inflammation in patients who discontinued MTX vs those who continued TCZ + MTX within the period of observation, consistent with the result of similar mean change in DAS28 between the groups in the primary analysis.

\section{REFERENCES:}

[1] Jones $\mathrm{G}$, et al. J Rheumatol 2017;44(2):142-146.

[2] Dougados M, et al. Ann Rheum Dis 2013;72(1):43-50.

[3] Strand V, et al. Arthritis Rheum 2013;65(10):2513-2523.

Acknowledgements: This study was funded by Genentech, Inc.

Disclosure of Interest: C. Peterfy Consultant for: Roche, Employee of: Spire Sciences, Inc., J. Kremer Shareholder of: Corrona, LLC, Consultant for: Abbvie, 